\title{
A contribution to the knowledge of Linaria tonzigii Lona, a steno-endemic species of the Orobie Bergamasche Regional Park (Italian Alps)
}

\section{Luca Giupponi \& Annamaria Giorgi}

Keywords: Linaria tonzigii, endemic species, CSR strategy, ecological indices, alpine plant, Orobie Bergamasche, Lombardy

\section{Abstract}

Linaria tonzigii is a rare steno-endemic species of Community interest that grows on some limestone screes in the Orobie Bergamasche Regional Park (Italian Alps). Information is scarce regarding its ecology (and especially synecology) and its Grime's CSR functional strategy. For this reason, this research, as well as analysing the floristic composition and ecology of the L. tonzigii community by means of traditional methods, also evaluated the Grime's CSR strategy of this endemic species using the latest methods and tools. Analysis of the phytosociological relevés conducted in five different areas revealed that the species constitutes a single plant community (the Linaria tonzigii-Hornungia alpina community) consisting of basophile and xerophile species mostly typical of limestone screes. The analysis of the CSR strategy revealed that the mean strategy of $L$. tonzigii is R/CSR, although the species presents slightly different strategies in the different sampling areas. This article reports the first ever data regarding inter-population variation in plant functional strategies in nature and suggests that the functional variability of the species is much wider than had been thought. The analysis of plant height of $L$. tonzigii also showed that the population isolated at the northern limit of the species' distribution range has significantly taller and less stress-tolerant individuals than those in other areas, suggesting that it may be a different ecotype. This article aims to stimulate researchers to study little-known endemic species in order to protect and valorize the biodiversity of protected areas.
Profile

Protected area

Orobie Bergamasche

\section{Regional Park}

Mountain range

Alps

Country

Italy

\section{Introduction}

The conservation of biodiversity is currently an issue of great importance and the subject of debate and action both locally and globally, as the extinction of species (animals and plants) can alter the functions of ecosystems and their services which are essential for human well-being (Fedele et al. 2017). In recent decades, many steps have been taken to protect rare and/or threatened species, from both legislative and applicative points of view. One example is the strategic plan for biodiversity of the Convention of Biological Diversity (Rio Earth Summit 1992), another the Habitat Directive (92/43/EEC), which is the most important strategy for nature conservation in Europe aimed at halting biodiversity loss. There are also many activities undertaken at various levels for the protection of species of conservation interest, such as the creation of Red Lists, ecological networks, protected areas or restocking plans.

In order to maximize the success of actions to protect rare and/or threatened species, a thorough knowledge of the different aspects of the species concerned is essential, including biological and ecological issues, which are particularly important for the correct implementation of conservation activities. Despite the progress of scientific research, there is still much work to be done to understand the ecology of countless species on Earth. In particular, it is essential to en- courage ecological studies of rare and / or threatened plants that are widespread only within a limited habitat (endemic species), or that are even extremely localized (steno-endemic species). Such species contribute to enriching and enhancing the prestige of the biological heritage of a given territory, and hence that of the whole planet.

One such example is Linaria tonzigii Lona (Plantaginaceae), a very rare plant which is steno-endemic to the Orobie Bergamasche Regional Park (Orobic Alps, Lombardy, Italy) (Pignatti 1982; Calegari et al. 1995; Aeschimann et al. 2004; Conti et al. 2005; Martini et al. 2012; Peruzzi et al. 2014; Andreis et al. 2017). This plant has so far been little studied, even though it was discovered over sixty years ago (Lona 1949). Currently, its presence is certain in just a few sites of the Orobic pre-Alps, many of which were refuge zones during the glaciations of the Quaternary Age: Mt. Arera / Mt. Corna Quadra group (locus classicus), Mt. Menna, Mt. Secco, Mt. Ferrante / Mt. Presolana group and Mt. Cavallo / Mt. Pegherolo group (Valoti 1996; Bendotti 1996; Pignatti 1982; Brissoni 1983; Crescini et al. 1985; Tagliaferri 1992; Martini et al. 2012; Giupponi \& Giorgi 2017). In such areas, L. tonzigii consists of fragmented populations in the subalpine and alpine belt (at around $2000 \mathrm{~m}$ altitude), always on limestone screes of Calcare di Esino formation (Upper Anisian - Ladinian). The characteristics of this species, in particular its rarity and its limited range, meant that 


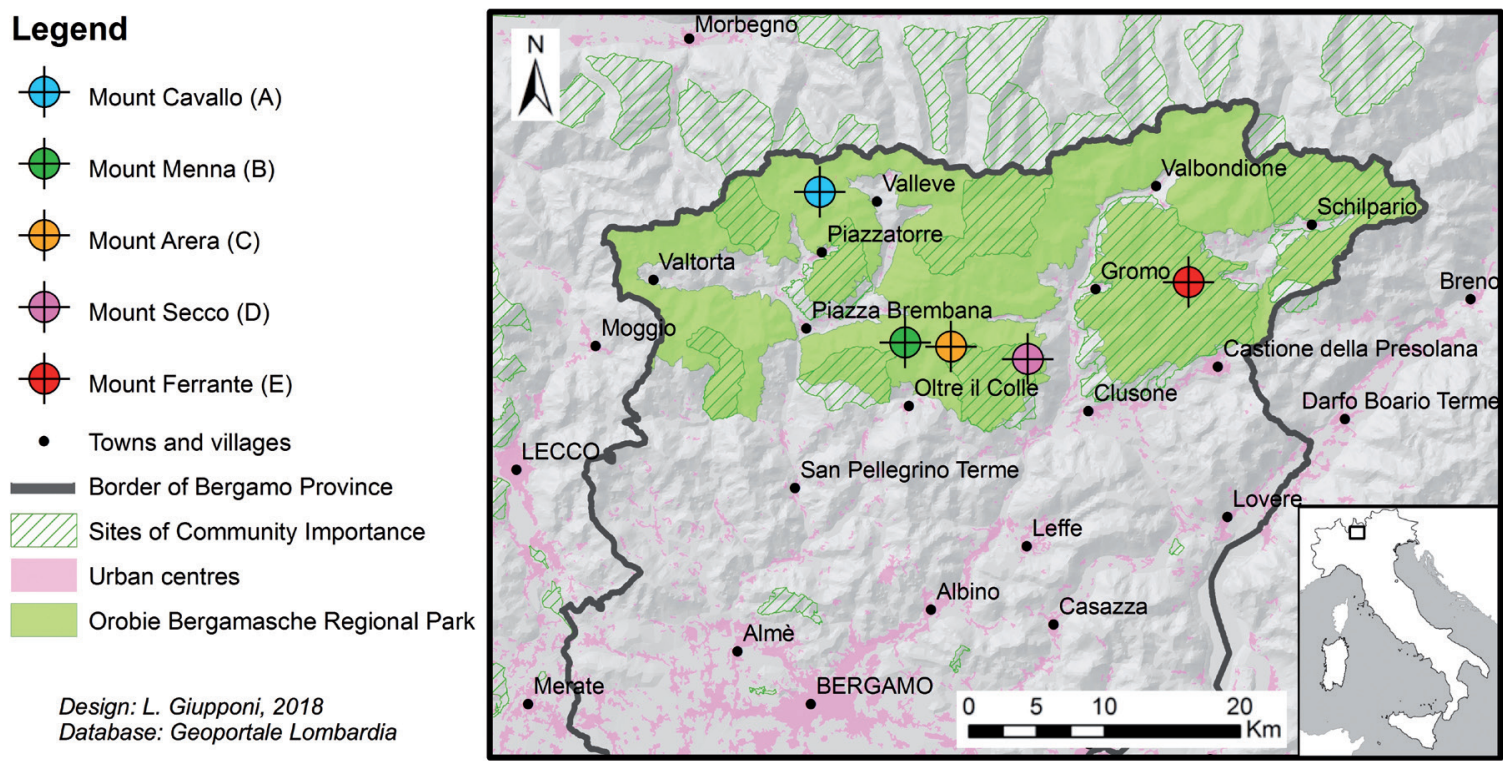

Figure 1 - Location of the five sampling areas: Mt. Cavallo (A); Mt. Menna (B); Mt. Arera (C); Mt. Secco (D); Mt. Ferrante (E). Latitude: $45^{\circ} 65^{\prime} \mathrm{N}$; Longitude: $9^{\circ} 48^{\prime} \mathrm{E}$.

it was chosen as a symbol of the Flora Alpina Bergamasca (FAB) group. According to the IUCN Red List of threatened species, L. tonzigii belongs to the category Endangered D (Mangili \& Rinaldi 2011) and it is therefore subject to strict protection in Lombardy under law LR10/2008. It is also a species of Community interest, included in Annex II of the Habitat Directive (92/43/EEC). Nevertheless, the populations of L. tonzigii are only partially included in Sites of Community Importance (SCIs).

In the past, ski runs were created near areas where L. tonrigii was found, and plans for the creation of pistes right on the screes where the species was present were put forward. Fortunately, these new runs were never created. Today, due to the lack of snow during the winter months, many of the ski runs have been closed and plans to create new ones no longer pose a threat to the species and its habitat.

Although the danger of anthropic disruption would seem to have been averted, other threats to the survival of the species, such as global warming, which can affect even alpine ecosystems, may loom (Körner 2003; Klanderud 2005; Rixen et al. 2014). It is therefore necessary to clarify the ecology of L. ton rigii and to define the functional strategies that the species has adopted in response to the environmental factors of the areas in which it lives. As regards the latter, Grime (1974, 1977, 2001) proposed the categorization of plants according to three strategies - competitors (C), stress tolerators (S) and ruderals (R) (CSR theory). This CSR classification has been applied to thousands of species in many different environments (including Alpine areas) (see e. g. Caccianiga et al. 2006; Pierce et al. 2007a,b, 2012, 2013, 2017; Simonová \& Lososová 2008; Massant et al. 2009; Cerabolini et al. 2010a, b; Kilinç et al. 2010; Navas et al. 2010; Yildirimet al. 2012; Mangili 2016; May et al. 2017). Although infor- mation is now available regarding the CSR strategies of many species that are widespread in the Alps (Cerabolini et al. 2010a; Pierce et al. 2017), the strategy of L. ton rigii is not present in these databases. Indeed, although Landolt et al. (2010) empirically attributed an rss (stress-tolerant ruderals) strategy to this species, no analyses based on precise measurements have ever been carried out.

In addition to analysing the floristic composition and ecology of the plant community of L. ton zigii, this study aims to evaluate the CSR strategy of this steno-endemic species using the recent method and CSR calculator tool of Pierce et al. (2017). The CSR strategy of $L$. tonzigii and its plant height were evaluated by considering the different populations found in various sites of the Orobie Bergamasche Regional Park (where the species is reported) in order to high-

Table 1 - Temperature (T), precipitation (P) and potential evapotranspiration (PE) from Mt. Arera weather station (2009-2017); data source: Centro Meteo Lombardo. PE was calculated using the online diagnosis tool developed by RivasSáenz (Rivas-Martinez \& Rivas-Sáenz 2009).

\begin{tabular}{|l|r|r|r|}
\hline Month & $\mathbf{T}\left[{ }^{\circ} \mathbf{C}\right]$ & $\mathbf{P}[\mathbf{m m}]$ & $\mathbf{P E}[\mathbf{m m}]$ \\
\hline January & -3.0 & 17.7 & 0.0 \\
\hline February & -2.6 & 32.7 & 0.0 \\
\hline March & 0.3 & 38.2 & 4.6 \\
\hline April & 3.0 & 71.6 & 29.4 \\
\hline May & 5.2 & 219.2 & 50.9 \\
\hline June & 9.9 & 268.5 & 83.7 \\
\hline July & 12.3 & 229.5 & 100.2 \\
\hline August & 12.2 & 230.2 & 92.0 \\
\hline September & 9.1 & 203.0 & 62.8 \\
\hline October & 4.9 & 177.2 & 35.5 \\
\hline November & 2.2 & 254.3 & 16.2 \\
\hline December & -0.8 & 47.6 & 0.0 \\
\hline Year & 4.4 & 1789.6 & 475.3 \\
\hline
\end{tabular}




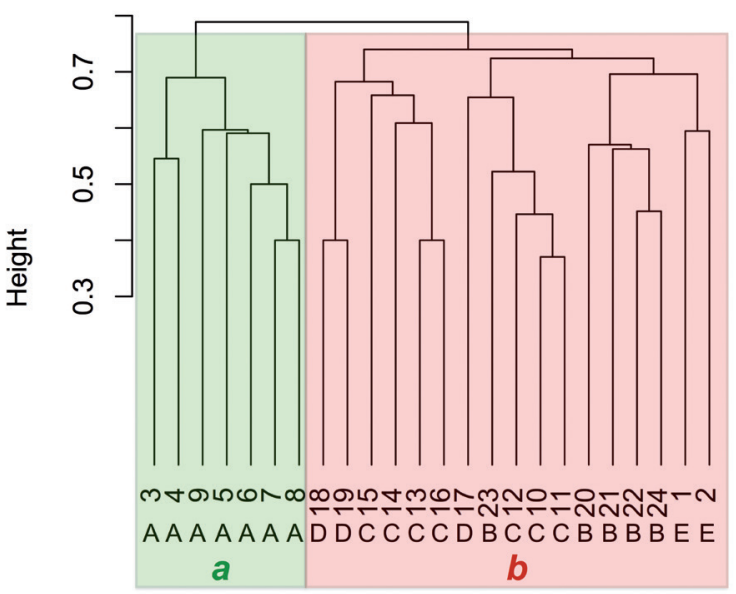

Figure 2 - Dendrogram of relevés. The numbers indicate the releve code; the capital letters indicate the area where the relevé was performed (A-Mt. Cavallo; B - Mt. Menna; C - Mt. Arera; D - Mt. Secco; E - Mt. Ferrante); the two clusters (a and b) are shown.

light any inter-population variations which could allow different ecotypes to be defined. In order to gain as complete a picture as possible of the adaptations of L. tonzigii (and its plant community) to the environment in which it lives, the functional strategy of L. tonrigii was also compared to that of other species that make up the plant community to which it belongs.

\section{Materials and methods}

Study areas and floristic-vegetational analysis

Data for the plant communities in which L. tonzigii is present were collected by performing several phytosociological relevés in five study areas of the preAlps of Bergamo province in which the species has been recorded (Valoti 1996; Bendotti 1996; Tagliaferri 1992; Martini et al. 2012; Giupponi \& Giorgi 2017): Mt. Cavallo (A), Mt. Menna (B), Mt. Arera (C), Mt. Secco (D) and Mt. Ferrante (E) (Figure 1). These areas are within the territory of the Orobie Bergamasche Regional Park, but not all are in Sites of Community Importance (SCIs). Their geological substrate is limestone rocks of Calcare di Esino formation. Table 1 shows data from the Mt. Arera weather station, which is located at $1950 \mathrm{~m}$ a.s.l. near a scree where L. tonzigii grows. This area lies in the orotemperate ultrahyperhumid bioclimatic belt of the temperate oceanic bioclimate (Rivas-Martínez \& Rivas-Sáenz 2009).

The phytosociological relevés were performed during the month of July 2017 using Braun-Blanquet's (1964) method over an area of $9 \mathrm{~m}^{2}$. Pignatti's (1982) dichotomous keys were used to identify species and to extrapolate information regarding their chorological type. The relevés were analysed statistically by means of cluster analysis (using the Jaccard index and the Unweighted Pair Group Method with Arithmetic Mean (UPGMA)) in order to evaluate the floristic similarity. The ecological analysis of the plant community (a)

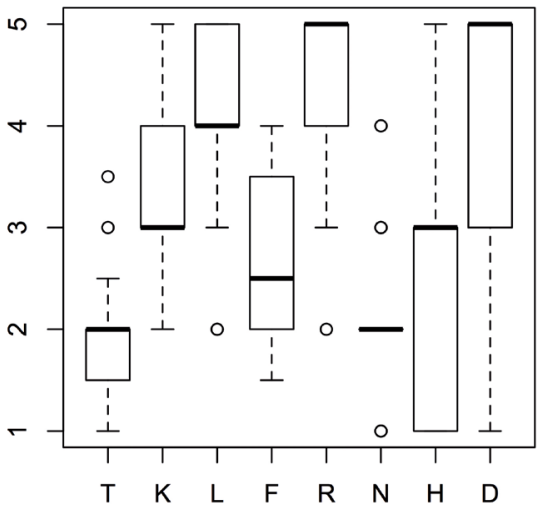

(b)

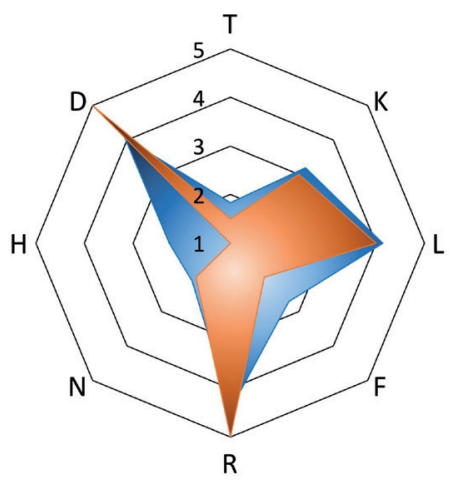

Linaria tonzigii

Plant community

Figure 3 - (a) Boxplot of ecological indices of the Linaria tonzigii-Hornungia alpina community; (b) radar graph of ecological features of Linaria tonzigii and that of its plant community. Key: $T$ - temperature; $K$ - continentality; $L$ - light; $F$ - soil moisture; $\mathrm{R}$ - reaction; $\mathrm{N}$ - nutrients; $\mathrm{H}$ - bumus; $D$ - aeration (Landolt et al. 2010).

(synecology) of L. tonzigii was performed by applying the ecological indices of Landolt et al. (2010). In each study area, the height of the stems of L. tonzigii bearing the inflorescences (racemes) was also measured in order to test for inter-population morphological differences. These data were analysed using an ANOVA test followed by Tukey's Honestly Significant Difference (HSD) test. Statistical analyses were performed using R 3.3.2 (R Core Team 2015) software. The scientific names of the species are in accordance with Martini et al. (2012).

\section{CSR analysis}

The CSR strategy of L. tonzigii was analysed according to the methods developed by Pierce et al. (2017). In each of the five areas where phytosociological relevés were performed (Figure 1), we collected 10 fully expanded leaves, if possible taken from different individuals. The plant material was wrapped in moist tissue paper and stored overnight in the laboratory, in the dark, at $4^{\circ} \mathrm{C}$. Leaf fresh weight $(\mathrm{LFW})$ was determined from these saturated samples using analytical balance (Precisa XB 220A), and the leaf area (LA) was measured using a digital scanner and ImageJ $1.50 \mathrm{i}$ software. Leaf dry weight (LDW) was measured after oven-drying at $105^{\circ} \mathrm{C}$ for $24 \mathrm{~h}$. CSR ternary coordi- 
Table 2 - Floristic composition of the Linaria tonzigii-Hornungia alpina community and presence of each species in the relevés (Pres. (\%)).

\begin{tabular}{|c|c|c|c|}
\hline No. & Species & Chorotype & Pres. (\%) \\
\hline 1 & Linaria tonzigii Lona & Endem. & 100 \\
\hline 2 & Hornungia alpina (L.) Appel & Centro-Europ. & 100 \\
\hline 3 & Sesleria caerulea (L.) Ard. & SE-Europ. & 83 \\
\hline 4 & Carex firma Host & Orof. S-Europ. & 79 \\
\hline 5 & Cerastium latifolium L. & Alpic-W-Carpatic & 75 \\
\hline 6 & Poa minor Gaudin & Orof. S-Europ. & 58 \\
\hline 7 & Crepis jacquinii subsp. kerneri (Rech. f.) Merxm. & Orof. SE-Europ. & 54 \\
\hline 8 & Adenostyles glabra (Mill.) DC. & Orof. S-Europ. & 50 \\
\hline 9 & Poa alpina $\mathrm{L}$. & Circumbor. & 50 \\
\hline 10 & Acinos alpinus (L.) Moench & Orof. S-Europ. & 46 \\
\hline 11 & Biscutella laevigata $\mathrm{L}$. & Orof. S-Europ. & 46 \\
\hline 12 & Festuca quadriflora Honck. & Orof. S-Europ. & 46 \\
\hline 13 & Thlaspi rotundifolium (L.) Gaudin subsp. rotundifolium & Endem. Alp. & 46 \\
\hline 14 & Doronicum grandiflorum Lam. & Orof. SW-Europ. & 42 \\
\hline 15 & Minuartia austriaca (Jacq.) Hayek & Endem. Alp. & 42 \\
\hline 16 & Campanula cochleariifolia Lam. & Orof. S-Europ. & 38 \\
\hline 17 & Viola dubyana Burnat ex Gremli & Endem. & 38 \\
\hline 18 & Achillea clavennae L. & E-Alp. - Dinaric & 33 \\
\hline 19 & Dryopteris villarii (Bellardi) Woyn. ex Schinz \& Thell subsp. villarii & Orof. S-Europ. & 33 \\
\hline 20 & Saxifraga aizoides $L$. & Circumbor. & 33 \\
\hline 21 & Carduus defloratus subsp. tridentinus (Evers.) Ladurner & Endem. Alp. & 29 \\
\hline 22 & Cystopteris alpina (Lam.) Desv. & Cosmopol. & 29 \\
\hline 23 & Galium baldense Spreng. & Endem. & 29 \\
\hline 24 & Athamanta cretensis L. & Orof. S-Europ. & 25 \\
\hline 25 & Hieracium bifidum Kit. ex Hornem. & Orof. S-Europ. & 25 \\
\hline 26 & Horminum pyrenaicum L. & Orof. SW-Europ. & 25 \\
\hline 27 & Juncus monanthos Jacq. & Artic-Alp. (Euro-Amer.) & 25 \\
\hline 28 & Rumex scutatus L. & S-Europ.-Sudsib. & 25 \\
\hline 29 & Saxifraga hostii subsp. rhaetica (A. Kern.) Braun-Blanq. & Endem. & 25 \\
\hline 30 & Arabis bellidifolia subsp. stellulata (Bertol.) Greuter \& Burdet & Medit.-Mont. & 21 \\
\hline 31 & Asplenium viride Huds. & Circumbor. & 21 \\
\hline 32 & Campanula raineri Perp. & Endem. & 21 \\
\hline 33 & Dryas octopetala L. & (Circum) Artic-Alp. & 21 \\
\hline 34 & Pedicularis tuberosa $\mathrm{L}$. & Orof. SW-Europ. & 21 \\
\hline 35 & Salix retusa $\mathrm{L}$. & Orof. Europ. & 21 \\
\hline 36 & Silene vulgaris subsp. glareosa (Jord.) Marsden-Jones \& Turrill & Orof. S-Europ. & 21 \\
\hline 37 & Veronica aphylla L. & Orof. S-Europ. & 21 \\
\hline 38 & Viola biflora L. & Circumbor. & 21 \\
\hline 39 & Aquilegia einseleana F.W. Schultz & Endem. Alp. & 17 \\
\hline 40 & Galium montis-arerae Merxm. \& Ehrend. & Endem. & 17 \\
\hline 41 & Persicaria vivipara (L.) Ronse Decr. & (Circum) Artic-Alp. & 17 \\
\hline 42 & Rhododendron hirsutum L. & Endem. Alp. & 17 \\
\hline 43 & Salix glabra Scop. & NE-Medit.-Mont. & 17 \\
\hline 44 & Saxifraga exarata subsp. moschata (Wulf.) Cavill. & Euro-Asiat. & 17 \\
\hline 45 & Trisetum distichophyllum subsp. brevifolium (Host) Pign. & Orof. S-Europ. & 17 \\
\hline 46 & Valeriana montana $\mathrm{L}$. & Orof. S-Europ. & 17 \\
\hline 47 & Anthyllis vulneraria L. subsp. baldensis (A. Kern.) Becker & Endem. & 13 \\
\hline 48 & Doronicum columnae Ten. & Orof. SE-Europ. & 13 \\
\hline 49 & Papaver alpinum subsp. rhaeficum (Leresche ex Gremli) & Endem. Alp. & 13 \\
\hline 50 & Primula glaucescens Moretti & Endem. & 13 \\
\hline 51 & Saxifraga sedoides L. & Orof. SW-Europ. & 13 \\
\hline 52 & Scrophularia juratensis Schleich. & Orof. S-Europ. & 13 \\
\hline 53 & Trisetum alpestre (Host) P. Beauv. & Orof. SE-Europ. & 13 \\
\hline 54 & Alchemilla nitida Buser & Orof. S-Europ. & 8 \\
\hline 55 & Asperula cynanchica L. & Euri-Medit. & 8 \\
\hline 56 & Bellidiastrum michelii Cass. & Orof. SE-Europ. & 8 \\
\hline 57 & Daphne striata Tratt. & Endem. Alp. & 8 \\
\hline 58 & Pedicularis rostratocapitata Crantz & E-Alp.-Carpat. & 8 \\
\hline 59 & Thymus praecox subsp. polytrichus (A. Kern. Ex Borbás) Ronniger & Orof. S-Europ. & 8 \\
\hline 60 & Allium insubricum Boiss. \& Reuter & Endem. & 4 \\
\hline 61 & Arabis alpina L. subsp. alpina & Circum-Artic-Alp. & 4 \\
\hline 62 & Carex austroalpina Bech. & Endem. & 4 \\
\hline 63 & Festuca alpestris Roem. \& Schult. & Endem. & 4 \\
\hline 64 & Galium anisophyllum Vill. & Orof. S-Europ. & 4 \\
\hline 65 & Gypsophila repens L. & Orof. S-Europ. & 4 \\
\hline 66 & Hieracium villosum Jacq. & Orof. SE-Europ. & 4 \\
\hline 67 & Homogyne alpina (L.) Cass. & Orof. Centro-Europ. & 4 \\
\hline 68 & Leontopodium alpinum Cass. & Orof. Euro-Asiat. & 4 \\
\hline 69 & Moehringia concarenae F. Fen. \& F. Martini & Endem. & 4 \\
\hline
\end{tabular}


Table 2 - continued

\begin{tabular}{|l|l|l|r|}
\hline No. & Species & Chorotype & Pres. (\%) \\
\hline 70 & Polystichum lonchitis (L.) Roth & Circumbor. & 4 \\
\hline 71 & Potentilla nitida L. & Subendem. & 4 \\
\hline 72 & Primula auricula L. & Orof. S-Europ. & 4 \\
\hline 73 & Ranunculus alpestris L. & Orof. S-Europ. & 4 \\
\hline 74 & Ranunculus thora L. & Orof. S-Europ. & 4 \\
\hline 75 & Rosa pendulina L. & S-Europ.-Sudsib. & 4 \\
\hline 76 & Saxifraga caesia L. & Orof. S-Europ. & 4 \\
\hline
\end{tabular}

nates (and CSR strategy) were determined using the StrateFy tool (Pierce et al. 2017) and were projected in the CSR ternary graph using the ggplot2 package of the software R 3.3.2 (R Development Core Team 2015). The CSR strategy of $L$. tonzigii was compared with the known strategies of other species of the relevés (Pierce et al. 2017).

\section{Results}

Twenty-four phytosociological relevés were performed in the five study areas (seven on Mt. Cavallo, five on Mt. Menna, seven on Mt. Arera, three on Mt. Secco and two on Mt. Ferrante) at altitudes ranging from $1850 \mathrm{~m}$ a.s.l. (Mt. Secco) to $2270 \mathrm{~m}$ a.s.l. (Mt. Ferrante). Table 2 lists the 76 species identified and their percentage presence in the relevés. Seven species are present in more than half of the relevés: L. tonzigii, Hornungia alpina, Sesleria caerulea, Carex firma, Cerastium latifolium, Poa minor and Crepis jacquinii subsp. kerneri. Most of the species identified are orophytes which are quite frequent in the Alps, but several endemic species are also present (in addition to L. tonzigii): Viola dubyana, Allium insubricum, Galium montis-arerae, Campanula raineri, Galium baldense and Moebringia concarenae. The dendrogram provided by cluster analysis (Figure 2) shows the level of floristic dissimilarity between the relevés and their subdivision into two clusters ( $a$ and $b)$. Cluster $a$ groups all the relevés performed in the

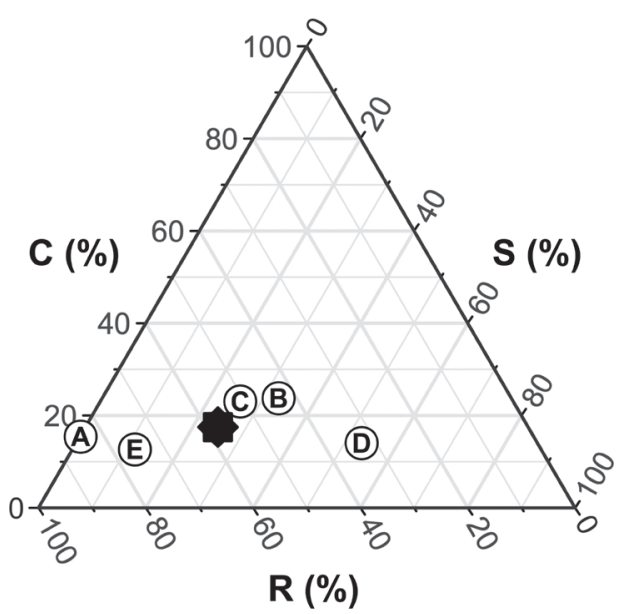

Figure 4 - CSR classification of Linaria tonzigii, showing CSR strategies of the plants of the five areas $(A-M t$. Cavallo; B - Mt. Menna; C - Mt. Arera; D - Mt. Secco; E-Mt. Ferrante) and mean strategy (black-filled star) of L. tonzigii. screes of Mt. Cavallo (A) which are differentiated from the others by the constant presence of Doronicum grandiflorum and Poa alpina; the relevés performed in the other four areas are all included in cluster $b$ since they present some species which are not present in the relevés of area A (Crepis jacquinii subsp. kerneri, Adenostyles glabra, Thlaspi rotundifolium, Acinos alpinus, Biscutella laevigata and Viola dubyana). Considering the slight floristic differences, the two clusters would seem to describe two variants of the same plant community, defined as Linaria tonzigii-Hornungia alpina, differentiated by the presence or absence of C. jacquinii subsp. kerneri, Adenostyles glabra, Thlaspi rotundifolium, Acinos alpinus, BiscuteIla laevigata and $V$. dubyana.

Figure 3 shows the ecological spectrum of the Linaria tonzigii-Hornungia alpina community with the relative average values of Landolt et al.'s (2010) indices and those referring to $L$. tonzigii. The plant community is made up of high-altitude heliophilous plants that live on coarse-grained, moderately dry soils which are highly basic and poor in nutrients. The radar graph (Figure $3 \mathrm{~b}$ ) shows that the ecology of the community (synecology) is very similar to that of $L$. tonzigii which, however, has lower values of $\mathrm{H}$ (humus) and $\mathrm{F}$ (soil moisture) but higher values of $\mathrm{R}$ (reaction) and $\mathrm{D}$ (aeration). This is due to the fact that the plant community includes some species that stabilize the screes (such as C. firma and Dryas octopetala) and favour the formation of discontinuous clods of soil (protorendzina), where less basophile species which require larger amounts of organic matter and humidity are found.

As regards the CSR strategy, the ternary graph in Figure 4 shows that the mean strategy of $L$. ton rigii is $\mathrm{R} / \mathrm{CSR}(\mathrm{C}: \mathrm{S}: \mathrm{R}=17.5: 25.0: 57.5)$, although there are some differences for the various populations (Table 3 and Figure 4) that highlight the species' ecological plasticity. In fact, the CSR strategy is R for the samples collected on Mt. Cavallo, SR / CSR for those on Mt. Menna, R/CSR for those on Mt. Arera, S / CSR for those on Mt. Secco, and R/ CR for those on Mt. Ferrante. The graph in Figure 5 shows the known CSR strategies of the species of the Linaria tonzigii-Hornungia alpina community, and the mean CSR strategy of this plant community (SR / CSR). The CSR values of the community (C:S:R=24.0:35.8:40.2) are slightly different from those of $L$. tonzigii due to the presence of several stress-tolerator species, such as $T$. rotundifolium, Saxifraga exarata subsp. moschata, Saxifraga caesia, Rhododendron birsutum, C. firma and D. octopetala. 
The boxplots in Figure 6 show that, in the Mt. Cavallo area (A), L. tonzigii presents stems that are taller than those measured in the other four areas. This observation is supported by the results of the ANOVA (which show that the five populations are significantly ( $p$-value $<10^{-4}$ ) different for plant height) and by the results of Tukey's HSD test, which shows, in particular, that the height of the Mt. Cavallo population samples is significantly ( $p$-value $<0.001$ ) different from that of all the other populations (Table 4).

\section{Discussions and conclusion}

Analyses provided interesting information regarding the plant community, ecology and CSR strategy of L. tonzigii. In particular, they showed that the same plant community (the Linaria tonzigii-Hornungia alpina community) is present in the various areas where the relevés were performed, but that the community has two variants due to the presence of certain species. As well as species which are geographically widespread and mostly of Thlaspion rotundifolii (which live on dry screes that are basic and poor in nutrients), the Linaria tonzigii-Hornungia alpina community also presents a fair number of steno-endemic species that characterize its floristic composition and pinpoint it to a precise geographic context - namely the limestone pre-Alps of Bergamo. The pre-Alpine district of Lombardy, where endemic species make up $15 \%$ of the flora, is the second most important centre of endemism in the alpine chain (Pawlowski 1970). This richness in endemic species is due to the fact that many pockets in the region were glacial refuges during the Quaternary Age (Giacomini \& Fenaroli 1958; Reisigl 1995; Andreis et al. 2017; Smyčka et al. 2017).

A step towards understanding the responses of L. tonzigii to its environment was achieved by evaluating its CSR strategy. According to the results of this research, $L$. tonzigii has a R/CSR strategy which is slightly different from the rss (stress-tolerant ruderals) attributed by Landolt et al. (2010), so this species must have developed morpho-physiological adaptations that allow it to withstand disturbance phenomena. In this case, the disturbance would be the movement of rocks and debris that make up the unstable screes where this endemic plant (and its plant community) lives and which, indeed, it requires. Although the mean strategy of $L$. ton zigii is R/CSR, the species presents slightly different adaptations/strategies in the different sampling areas (Figure 4 and Table 3). In particular, it would seem that the plants on Mt. Cavallo and those on Mt. Ferrante have a clear predominance of the ruderal component $(\mathrm{R})$ and low values of the stress-tolerator (S) (which is zero for the Mt. Cavallo samples) and competitive (C) components, while the plants collected in the remaining areas, especially those of Mt. Secco, have developed greater adaptations to stress. This may be because in the southernmost areas (Mt. Menna, Mt. Arera and Mt. Secco; Figure 1), where the species also
Table 3 - Means and standard errors of $C, S$ and $R$ percentages of Linaria tonzigii in each study area (A-Mt. Cavallo; $B-M t$. Menna; $C-M t$. Arera; D-Mt. Secco; E - Mt. Ferrante).

\begin{tabular}{|c|c|c|c|c|c|c|c|}
\hline Study area & C (\%) & $\mathrm{S}(\%)$ & $\mathbf{R}(\%)$ & Study area & C (\%) & $\mathrm{S}(\%)$ & R (\%) \\
\hline \multirow{10}{*}{$A(n=10)$} & 15.29 & 0.00 & 84.71 & \multirow{10}{*}{$D(n=10)$} & 1.95 & 92.97 & 5.08 \\
\hline & 18.22 & 0.00 & 81.78 & & 1.81 & 93.23 & 4.96 \\
\hline & 23.02 & 0.00 & 76.98 & & 23.34 & 0.00 & 76.66 \\
\hline & 16.72 & 0.00 & 83.28 & & 18.25 & 72.14 & 9.61 \\
\hline & 25.04 & 0.00 & 74.96 & & 23.40 & 71.39 & 5.21 \\
\hline & 14.39 & 0.00 & 85.61 & & 6.14 & 47.79 & 46.07 \\
\hline & 11.73 & 0.00 & 88.27 & & 15.78 & 64.57 & 19.65 \\
\hline & 10.08 & 0.00 & 89.92 & & 21.70 & 49.86 & 28.44 \\
\hline & 11.08 & 0.00 & 88.92 & & 10.84 & 27.36 & 61.80 \\
\hline & 8.41 & 0.00 & 91.59 & & 16.11 & 13.38 & 70.51 \\
\hline Mean & \begin{tabular}{|l|l}
15.40 \\
\end{tabular} & 0.00 & 84.60 & Mean & 13.93 & 53.27 & 32.80 \\
\hline$\pm \mathrm{SD}$ & 5.49 & 0.00 & 5.49 & $\pm S D$ & 8.34 & 31.84 & 28.67 \\
\hline \multirow{10}{*}{$B(n=10)$} & 35.70 & 44.62 & 19.68 & \multirow{10}{*}{$E(n=10)$} & 23.63 & 0.00 & 76.37 \\
\hline & 40.12 & 12.17 & 47.71 & & 27.12 & 0.00 & 72.88 \\
\hline & 33.14 & 45.90 & 20.96 & & 13.33 & 0.00 & 86.67 \\
\hline & 9.53 & 0.00 & 90.47 & & 14.26 & 0.00 & 85.74 \\
\hline & 16.95 & 56.95 & 26.10 & & 7.63 & 0.00 & 92.37 \\
\hline & 18.01 & 24.52 & 57.47 & & 13.44 & 24.55 & 62.01 \\
\hline & 17.41 & 55.62 & 26.97 & & 14.19 & 0.71 & 85.09 \\
\hline & 8.09 & 0.00 & 91.91 & & 8.38 & 0.00 & 91.62 \\
\hline & 7.61 & 62.50 & 29.90 & & 1.93 & 63.92 & 34.15 \\
\hline & 44.23 & 32.14 & 23.64 & & 2.70 & 29.68 & 67.62 \\
\hline Mean & 23.08 & 33.44 & 43.48 & Mean & 12.66 & 11.89 & 75.45 \\
\hline$\pm \mathrm{SD}$ & 13.91 & 23.43 & 27.88 & $\pm S D$ & 8.12 & 21.49 & 17.72 \\
\hline \multirow{10}{*}{$C(n=10)$} & 25.79 & 0.00 & 74.21 & Total $(n=50)$ & C (\%) & S (\%) & R (\%) \\
\hline & 34.64 & 28.82 & 36.54 & Mean & 17.49 & 25.02 & 57.49 \\
\hline & 1.95 & 93.30 & 4.74 & $\pm \mathrm{SD}$ & 10.72 & 30.07 & 29.55 \\
\hline & 49.75 & 0.00 & 50.25 & & & & \\
\hline & 19.67 & 41.68 & 38.64 & & & & \\
\hline & 15.68 & 47.65 & 36.67 & & & & \\
\hline & \begin{tabular}{|l|l}
17.41 \\
\end{tabular} & 0.00 & 82.59 & & & & \\
\hline & 16.68 & 53.61 & 29.71 & & & & \\
\hline & 22.95 & 0.00 & 77.05 & & & & \\
\hline & 19.24 & 0.00 & 80.76 & & & & \\
\hline Mean & 22.38 & 26.51 & 51.12 & & & & \\
\hline$\pm \mathrm{SD}$ & 12.68 & 32.30 & 26.38 & & & & \\
\hline
\end{tabular}

Table 4 - p-values returned by Tukey's HSD test for the plant height of the samples of each study area $(A-M$ t. Cavallo; B - Mt. Menna; C - Mt. Arera; D - Mt. Secco; E - Mt. Ferrante). Sample sizes: $A=35 ; B=53 ; C=130 ; D=22$; $E=9$. p-values $<0.001$ are bighlighted in bold.

\begin{tabular}{|l|l|l|l|l|l|}
\hline Sampling area & A & B & C & D & E \\
\hline A & - & 0.00000 & 0.00000 & 0.00007 & 0.00099 \\
\hline B & & - & $\mathbf{0 . 6 7 0 7 4}$ & $\mathbf{0 . 6 3 2 2 5}$ & $\mathbf{0 . 9 9 6 5 7}$ \\
\hline C & & & - & $\mathbf{0 . 9 7 6 3 6}$ & $\mathbf{0 . 9 9 9 0 1}$ \\
\hline D & & & & - & $\mathbf{0 . 9 7 9 3 3}$ \\
\hline E & & & & & - \\
\hline
\end{tabular}

grows at lower altitudes, L. tonzigii populations have developed greater adaptations to stress, which, in this case, could be the high summer temperatures. Indeed, according to Grime (2001), sub-optimal temperature is one phenomenon that can restrict photosynthetic production (which represents a stress factor for the 


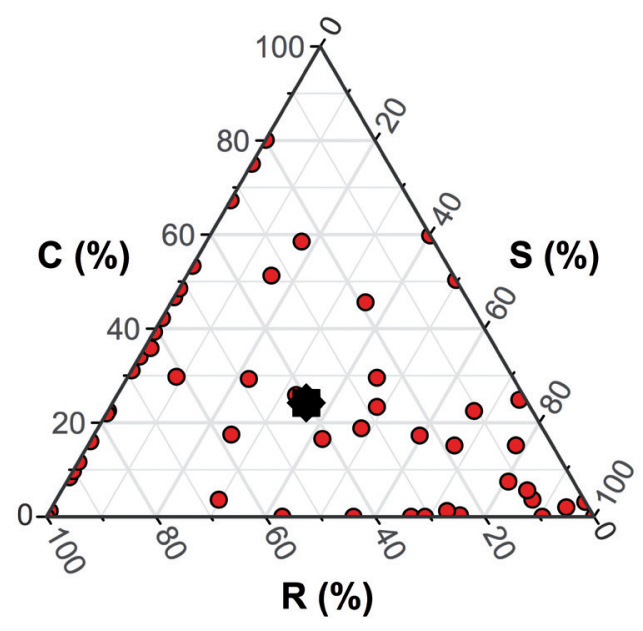

Figure 5-CSR strategies of the species of the Linaria tonzigii-Hornungia alpina community (red dots) and mean strategy of the community (black-filled star).

plants). Moreover, May et al. (2017) demonstrated that intra-specific variation in plant functional strategies may be due to climate adaptation. In particular, they observed an intra-specific variation between Arabidopsis thaliana accessions (grown under controlled environmental conditions) along the S-R axis, similar to that observed in our research on $L$. tonzigii plants growing in nature, in which the greatest variation was indeed for the components $\mathrm{R}$ and $\mathrm{S}$ (Table 3 ).

In order to understand whether the temperatures of the sampling areas really are different, it would be appropriate to conduct further field measurements and analyse the data, which might highlight the new threat to L. tonzigii populations (at least for those on the southernmost slopes) posed by climate warming. It would also be interesting to measure the accumulation of snow in the various areas where $L$. tonzigii is present, as well as to evaluate the speed at which the snow on the screes melts and the period during which this happens in order to understand whether particularly rapid and / or early melting can cause water stress to the plant during the summer months. In fact, according to Leuschner \& Ellenberg (2017), the scree plants of alpine and subalpine environments should have good availability of water (below the dry, stony material) during the summer period from the melting of the snow cover. The absence of this source of water during the summer (due to little accumulation of snow during the winter or the fact that the snow melted too early) could represent a further stress for L. tonzigii (closely linked to the rise in temperatures and exposure) that could explain the different CSR strategy of the plants in the various sampling areas. Similarly, a greater adaptation to stress could also be due to a greater lack of nutrients in the substrate. Indeed, according to Zöttl (1952) and Leuschner \& Ellenberg (2017) the dust contained in the snow provides a significant contribution of nutrients to the plants of the limestone scree.

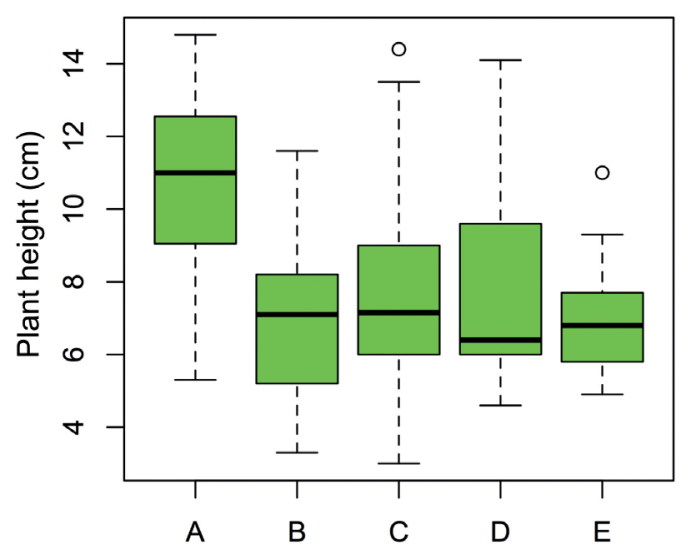

Figure 6 - Boxplots of plant height of individuals of Linaria tonzigii in the five study areas ( $A-M t$. Cavallo; $B-M t$. Menna; C - Mt. Arera; D - Mt. Secco; E - Mt. Ferrante). Number of samples per area: $A=35 ; B=53 ; C=130$; $D=22 ; E=$.

The assessment of the mean CSR strategy of the Linaria tonzigii-Hornungia alpina community (Figure 5) has provided an overall picture of the strategies of the species (or the CSR fingerprint of the community), even though the functional strategy of some species (25 out of 76) is not known. This analysis shows that the CSR values of $L$. tonzigii are very different from those of other herbaceous alpine species typical of screes (which very often grow together), such as Hornungia alpina (C:S:R = $1.2: 0.0: 98.8)$, Thlaspi rotundifolium (C:S:R = $3.2: 96.8: 0.0)$, Campanula cochleariïflia (C:S:R = $3.6: 29.7: 66.7)$, Saxifraga aizoides (C:S:R = $0.0: 66.6: 33.4)$, Carex firma (C:S:R $=3.7: 86.9: 9.4$ ), Cerastium latifolium (C:S:R = $16.1: 0.0: 83.9)$, and $L$. alpina (C:S:R = $0.4: 9.6: 90.0$; original data). This may be due to the fact that plants with different growing strategies live together in the screes (scree wanderers, scree creepers, scree stabilizers, scree coverers, scree accumulators; Schröter 1926; Jenny-Lips 1930). These scree-living plants can be organized into three main groups: 1) passive scree wanderers; 2) scree creepers and coverers; 3) scree accumulators and stabilizers (Leuschner \& Ellenberg 2017). Therefore, scree plants with different growing strategies could have different CSR strategies, even though they are present in the same environments. This requires confirmation from further studies, which would further enhance knowledge of the peculiarities of the plant communities of the scree. It would also be worth considering whether, in addition to $L$. tonzigii, other scree plants (or plants in other environments) have a wider range of variability in CSR strategies. Our study highlights (as does that of May et al. (2017)) that some species may have different CSR strategies based on the different sites in which they grow, hence suggesting that the functional variability of a species is much wider than has so far been apparent. In future, it would therefore be advisable to evaluate the functional variability (and mean strategy) of each plant species, in particular those of which the 
CSR strategy was evaluated starting from plant material collected only at a single site and taken from a few individuals (as was the case for almost all the species of which the CSR strategy was already known).

From an overall analysis of the results of this work, it is also apparent that, in the Mt. Cavallo area, L. ton rigii presents morphological characteristics (plant height) and a functional strategy that, along with the floristic composition of the plant community to which it belongs, differentiate it from the populations of other areas. This would lead us to conclude that the Mt. Cavallo population could be a different ecotype. Indeed, the Mt. Cavallo population is very isolated from the others and located at the northern limit of the L. tonzigii distribution range. These conditions, together with the probably harsher temperatures, may have favoured the differentiation of this ecotype, a hypothesis which should, however, be verified by further studies.

In conclusion, this research, as well as stimulating a more in-depth study of variability in the CSR strategies of plants, enriches knowledge regarding L. tonzigii and its community. We hope that, in the next few years, similar research can be carried out for other little-known endemic and / or rare and / or threatened species so as to enrich knowledge of their ecology and of their communities, an essential step when planning conservation measures for such species and their environment, and to protect the biodiversity of the protected areas, and hence that of the planet.

\section{Acknowledgements}

We would like to thank Paolo Bosio for his help during our visits to the study area and for his work in the laboratory, and Murizio Andreozzi for the Mt. Arera weather station data.

This study was supported by Accordo di collaborazione fra Regione Lombardia e Ge.S.Di.Mont. per attività di ricerca scientifica ed applicata e di diffusione della conoscenza inerente il territorio montano lombardo (art. 4 c.7 l.r. 22/2016) and by the FISR-MIUR Italian Mountain Lab project.

\section{References}

Aeschimann, D., K. Lauber, D.M. Moser \& J.-P. Theurillat 2004. Flora alpina. Bern-Stuttgart-Wien. [In German]

Andreis, C., S. Armiraglio, M. Caccianiga, B. Cerabolini \& C. Ravazzi 2017. Alpi Orobie e Prealpi Carbonatiche: un hot spot di endemicità. In: Blasi, C. \& E. Biondi (eds.), La flora in Italia: 100-103. Roma. [In Italian]

Bendotti, M. 1996. Precisazioni sulla Linaria tonzigii. Not. Florist. Flora Alpina Bergamasca 10: 24. [In Italian]

Braun-Blanquet, J. 1964. Pflanzensoziologie. Wien. [In German]

Brissoni, C. 1983. Vivere con i fiori, introduzione alla flora alpine bergamasca e delle Prealpi Lombarde. Clusone (BG). [In Italian]
Caccianiga, M., A. Luzzaro, S. Pierce, R.M. Ceriani \& B. Cerabolini 2006. The functional basis of a primary succession resolved by CSR classification. Oikos 112: 10-20.

Cerabolini, B.E.L., G. Brusa, R.M. Ceriani, R. De Andreis, A. Luzzaro \& S. Pierce 2010a. Can CSR classification be generally applied outside Britain? Plant Ecology 253: 261.

Cerabolini, B.E.L., S. Pierce, A. Luzzaro \& A. Ossola 2010b. Species evenness affects ecosystem processes in situ via diversity in the adaptive strategies of dominant species. Plant Ecology 207: 333-345.

Conti, F., G. Abbate, A. Alessandrini \& C. Blasi 2005. An annotated checklist of Italian flora. Roma.

Crescini, A., F. Fenaroli \& F. Tagliaferri 1985. Segnalazioni floristiche bresciane. Natura Bresciana Riv. Mus. Civ. Sc. Nat. Brescia 20: 93-104. [In Italian]

Fedele, G., B. Locatelli \& H. Djoudi 2017. Mechanisms mediating the contribution of ecosystem services to human well-being and resilience. Ecosystem Services 28: 43-54.

Giacomini, V. \& L. Fenaroli 1958. La flora. Milano. [n Italian]

Giupponi, L. \& A. Giorgi 2017. Mount Cavallo Botanical Path: a proposal for the valorization of an area of the Orobie Bergamasche Regional Park (Southern Alps). eco.mont 9(2): 5-15.

Grime, J.P. 1974. Vegetation classification by reference to strategies. Nature 250: 26-31.

Grime, J.P. 1977. Evidence for the existence of three primary strategies in plants and its relevance to ecological and evolutionary theory. The American Naturalist 111: 1169-1194.

Grime, J.P. 2001. Plant strategies, vegetation processes and ecosystem properties. Chichester.

Jenny-Lips, H. 1930. Vegetationsbedingungen und Pflanzengesellschaften auf Felsschutt. Beih. Bot. Cbl. 46: 119-296. [In German]

Kilinç, M., N. Karavin \& H.G. Kutbay 2010. Classification of some plant species according to Grime's strategies in a Quercus cerris L. var. cerris woodland in Samsun, northern Turkey. Turkish Journal of Botany 34: 521-529.

Klanderud, K. 2005. Clima change effects on species interactions in an alpine plant community. Journal of Ecology 93: 127-137.

Körner, C. 2003. Alpine plant life. Functional plant ecology of high mountain ecosystems. Berlin, Heidelberg.

Landolt, E., B. Bäumler, A. Erhardt, O. Hegg, F. Klötzli, R.W. Lämmle, M. Nobis, K. Rudmann-Mayree, H.F. Schweingruber, J.P. Theurillat, E. Urmi, M. Vust \& T. Wohlgemuth 2010. Flora indicativa. Ecological indicator values and biological attributes of the Flora of Switzerland and the Alps. Bern-Stuttgart-Wien.

Leuschner, C. \& H. Ellenberg 2017. Ecology of Central European Non-Forest Vegetation: Coastal to Alpine, Natural to Man-Made Habitats. Vegetation Ecology of Central Europe, Vol II. Cham. 
Lona, F. 1949. Nuova specie di Linaria rinvenuta al Pizzo Arera (Alpi Orobie). Natura Riv. Sc. Nat. Ed. Soc. Ital. Sc. Nat. Milano XL (3-4): 65-72. [In Italian]

Massant, W., S. Godefroid \& N. Koedam 2009. Clustering of plant life strategies on meso-scale. Plant Ecology 205: 47-56.

Mangili, F. 2016. Corologia, autoecologia e sinecologia di Androsace brevis (Hegetschw.) Ces. (Primulaceae). $\mathrm{PhD}$ dissertation, University of Milan, Milan. [In Italian]

Mangili, F. \& G. Rinaldi 2011. Linaria tonzigii. The IUCN Red List of Threatened Species 2011: e.T162172A5553011. Available at: http:// dx.doi.org/10.2305/IUCN.UK.2011-1.RLTS. T162172A5553011.en (accessed 20/11/2017)

Martini, F., E. Bona, G. Federici, F. Fenaroli, G. Perico, S. Danieli, G. Fantini, L. Mangili, F. Tagliaferri \& E. Zanotti 2012. Flora vascolare della Lombardia centroorientale. Trieste. [In Italian]

May, R.-L., S. Warner \& A. Wingler 2017. Classification of intra-specific variation in plant functional strategies reveals adaptation to climate. Annals of Botany 119: 1343-1352.

Navas, M.L., C. Roumet, A. Bellmann, G. Laurent \& E. Garnier 2010. Suites of plant traits in species from different stages of a Mediterranean secondary succession. Plant Biology 12: 183-196.

Pawlowski, B. 1970. Remarques sur l'endémisme dans la flore des Alpes et des Carpates. Vegetatio 21: 181-243. [In French]

Peruzzi, L., F. Conti \& F. Bartolucci 2014. An inventory of vascular plants endemic to Italy. Phytotaxa 168: 3-75.

Pignatti, S. 1982. Flora d'Italia. Bologna. [In Italian]

Pierce, S., G. Brusa, M. Sartori \& B.E.L. Cerabolini 2012. Combined use of leaf size and economics traits allows direct comparison of hydrophyte and terrestrial herbaceous adaptive strategies. Annals of Botany 109: 1047-1053.

Pierce, S., G. Brusa, I. Vagge, B.E.L. Cerabolini 2013. Allocating CSR plant functional types: the use of leaf economics and size traits to classify woody and herbaceous vascular plants. Functional Ecology 27: 1002-1010.

Pierce, S., R.M. Ceriani, R. De Andreis, A. Luzzaro \& B.E.L. Cerabolini 2007a. The leaf economics spectrum of Poaceae reflects variation in survival strategies. Plant Biosystems 141: 337-343.

Pierce, S., A. Luzzaro, M. Caccianiga, R.M. Ceriani \& B.E.L. Cerabolini 2007b. Disturbance is the principal a-scale filter determining niche differentiation, coexistence and biodiversity in an alpine community. Journal of Ecology 95: 698-706.

Pierce, S., D. Negreiros, B.E.L. Cerabolini et al. 2017. A global method for calculating plant CSR ecological strategies applied across biomes world-wide. Functional Ecology 31: 444-457.

R Development Core Team 2015 R: A language and environment or statistical computing. R Foundation for Statistical Computing, Vienna.
Available at: http://www.r-project.org (accessed 20/11/2017)

Reisigl, H. 1995. Insubrien und das Gardaseegebiet, vegetation, florengeschichte, endemismus. Annali del Museo Civico di Rovereto 11: 9-25. [In German]

Rivas-Martínez, S. \& S. Rivas-Sáenz 2009. Sistema de Clasificación Bioclimática Mundial. Centro de Investigaciones Fitosociológicas, España. Available at: http://pendientedemigracion.ucm.es/info/cif/ (accessed 20/11/2017)

Schröter, C. 1926. Das Pflanzenleben der Alpen. $2^{\text {nd }} e d$. Zürich. [In German]

Simonová, D. \& Z. Lososová 2008. Which factors determine plant invasions in man-made habitats in the Czech Republic? Perspectives in Plant Ecology, Evolution and Systematics 10: 89-100.

Smyčka, J., C. Roquet, J. Renaud, W. Thuiller, N.E. Zimmermann \& S. Lavergne S 2017. Disentangling drivers of plant endemism and diversification in the European Alps - A phylogenetic and spatially explicit approach. Perspective in Plant Ecology, Evolution and Systematics 28: 19-27.

Tagliaferri, F. 1992. Segnalazioni floristiche per la Val di Scalve: 1-5. Natura Bresciana Ann. Mus. Civ. Sci. Nat. Brescia 27: 99-101. [In Italian]

Valoti, M. 1996. Distribuzione territoriale di Linaria tonzigii Lona (Scrophulariaceae) in Bergamasca. Not. Florist. Flora Alpina Bergamasca 9: 13-14. [In Italian]

Yildirim, C., N. Karavin \& A. Cansaran 2012. Classification and evaluation of some endemic plants from Turkey using Grime's CSR strategies. EurAsian Journal of BioSciences 6: 97-104.

Zöttl, H. 1952. Beitrag zur Ökologie alpiner Kalkschuttstandorte. Phyton 4: 160-175. [In German]

\section{Authors}

\section{Luca Giupponi}

is a botanist of CRC Ge.S.Di.Mont., an expert in the flora of the Alps, plant ecology and phytosociology. He deals with the study of plants / plant communities and everything related to the valorization of mountain areas. E-mail: luca.giupponi@unimi.it

\section{Annamaria Giorgi $i^{1,2}$}

is the scientific coordinator of CRC Ge.S.Di.Mont. and is experienced in the management of public institutions dealing with research activities. She was formerly the president of ISCAR and now represents the Lombardy Region in the EU Strategy for the Alpine Region. E-mail: anna.giorgi@unimi.it

${ }^{1}$ Centre of Applied Studies for the Sustainable Management and Protection of Mountain Areas CRC Ge.S.Di.Mont., University of Milan, Via Morino 8, 25048 Edolo (BS), Italy.

2 Department of Agricultural and Environmental Sciences - Production, Landscape and Agroenergy, University of Milan, Via Celoria 2, 20133 Milan (MI), Italy. 